\title{
VPRAŠANJE AVTONOMNOSTI GLASBENE KRITIKE V SLOVENSKEM DNEVNEM ČASOPISJU OB PRAIZVEDBI KANTATE STARA PRAVDA MATIJE TOMCA: MED ESTETSKO SODBO IN POLITIČNIM KONSTRUKTOM
}

\author{
JERNEJ WEISS \\ Filozofska fakulteta Univerze v Ljubljani
}

Izvleček: Akademski pevski zbor Tone Tomšič je sklenil 10-letnico svojega delovanja leta 1956 obeležiti z jubilejnim koncertom. Za počastitev omenjenega dogodka je skladatelj Matija Tomc uglasbil kantato Stara Pravda, ki je bila praizvedena 12. marca 1956 v veliki Unionski dvorani. Izvedba je naletela na ostre odzive ortodoksnih marksističnih ideologov, ki so, zdi se, vodstvu zbora zamerili predvsem, da je po koncertu počastilo skladateljski prispevek katoliškega intelektualca Matije Tomca. Vodilni partijski ideologi so zaradi neljubega dogodka pritisnili na zbor tako močno, da je le ta izgubil dirigenta in tako skorajda razpadel $v$ začetni, desetletje trajajoči povojni formaciji.

Ključne besede: Stara pravda, Matija Tomc, Akademski pevski zbor Tone Tomšič, glasbena kritika

\begin{abstract}
The Tone Tomšič Academic Choir decided to celebrate the tenth anniversary of its work with a jubilee concert. To celebrate the above-mentioned event, the composer, Matija Tomc, composed the cantata Stara Pravda (Old Justice), first performed on 12 March 1956 in the large Union Hall. The performance met with sharp reactions on the part of orthodox Marxist ideologists, who after the concert seemed to have especially resented the decision of the choir's management to honour the contribution of the composer, the Catholic intellectual, Matija Tomc. The leading party ideologists put such strong pressure on the choir that it lost its conductor and thus nearly dissolved in its formative, ten-year post-war phase.
\end{abstract}

Keywords: Old Justice, Matija Tomc, The Tone Tomšič Academic Choir, music review

Muzikološke raziskave večkrat temeljijo na takšnih ali drugačnih vnaprej postavljenih konceptih, ki naj bi jih muzikološka znanost dokazala in potrdila. Ti koncepti imajo pogosto svoja ideološka ozadja ali jih je vsaj mogoče povezovati z njimi. ${ }^{1}$ Vsako obdobje naj bi namreč sledeč ideologiji interpretiralo zgodovino po svoje in postavilo lastne kriterije za selekcijo historiografskega materiala. Tako je toliko bolj pomembno tisto, kar je z določenim namenom izpuščeno ali dodano in nima nobene zveze $\mathrm{z}$ realnimi

1 Nacionalni koncept zgodovine iz druge polovice 19. stoletja svoje pojmovanje svobode izpostavlja na ta način, da ustvari legendo o nekoč izgubljeni svobodi, ki pa si jo je narod s trudom in junaško priboril in tako uveljavil svojo nacionalno integriteto in suverenost. Tatjana Rozman, Ideološke vsebine zgodovine na Slovenskem, Nova revija 8 (1989), 89-90, str. 1249. 
zgodovinskimi dejstvi. Za ideologijo posebno značilen je pretanjen način vrednotenja pojavov, posebno tistih, ki imajo takšen ali drugačen pomen tudi za sedanjost. Druga značilnost je bistveno odstopanje od znanstvenih metod. Tretja pa enostransko uporabljanje informacij. Treba se je zavedati, da morejo omenjeni koncepti deformirati resnično podobo glasbene zgodovine, ${ }^{2}$ zato je potrebno biti toliko bolj previden pri izhajanju iz tovrstnih okvirov in ocenjevanju lastnih sklepov. Tako se zdi pomembno k zgodovinski analizi pritegniti nove vire, ki jim zgodovinarji tradicionalno niso posvečali pozornosti in zavzeti kritično distanco do nekaterih sekundarnih glasbeno-zgodovinskih virov iz polpreteklega obdobja.

Avtor edinega zgodovinskega pregleda slovenske glasbe 20. stoletja Niall O'Loughlin v opisu slovenske glasbe v obdobju po letu 1945 ne navaja pojma »socialistična umetnost«, za razliko od nekaterih drugih avtorjev, ki ga opredeljujejo. Lojze Lebič govori o »normativni estetiki«, ${ }^{3}$ Ivan Klemenčič o »zapovedanem modelu«, ${ }^{4}$ Gregor Pompe pa o »doktrini«. ${ }^{5}$ Leon Stefanija ob prikazu različnih interpretacij socialističnega realizma v glasbenozgodovinski literaturi pri nas določi skupni imenovalec različnim družbenim oziroma kompozicijskim spremenljivkam ter zapiše da: »[...] ima socialistični realizem svoje korenine v neposredni preteklosti 'varnega tradicionalizma', višek v pogledih na avtonomijo ali odvisnost in konec $\mathrm{v}$ glasbenih poetikah selektivnega brzdanja. ${ }^{6}$ Resnica o vrednosti avtonomnega razvoja je upoštevajoč zadnji okvir zanikana, umetnost in posebej glasba pa mora poslej prisilno držati ogledalo družbi, s čimer je prisiljena da nehote negira čas, v katerem je nastala. ${ }^{7}$ To naj bi pomenilo opustitev avtonomnih estetik in razvojno diskontinuiteto slovenske glasbe. ${ }^{8}$ Kljub zapovedanosti socialističnega realizma pa model te ideološko pogojene umetnosti pri nas ni bil nikdar jasno opredeljen. ${ }^{9}$

Nova oblast v konkretna glasbeno-estetska vprašanja ni posegala, temveč predvsem obvladovala upraviteljske položaje, od koder je potem demoralizirala nezaželene pobude. Agitacijska učinkovitost je torej zahtevala zamenjavo estetskih meril s praktičnimi. Slovenski skladatelji in glasbene institucije so bili tako predvsem v veliki meri

2 Konkretna zgodovinska realnost se prilagodi idealni predstavi pravljice. Tako sta na primer v slovenskih zgodovinskih učbenikih po koncu 2. svetovne vojne glavna protagonista »hudobna« buržoazija na eni in brezpogojno »pravična« partija na čelu proletariata na drugi strani. Nav. delo, str. 1245.

3 Lojze Lebič, Glasovi časov (II), O slovenski glasbeni ustvarjalnosti, Naši zbori 45 (1993), 5-6, str. 114.

4 Ivan Klemenčič, Glasba in totalitarna država na Slovenskem, Temna stran meseca: kratka zgodovina totalitarizma v Sloveniji 1945-1990, ur. Drago Jančar, Ljubljana, Nova revija, 1998, str. 325.

5 Jurij Snoj in Gregor Pompe, Pisna podoba glasbe na Slovenskem, Ljubljana, Založba ZRC, ZRC SAZU, 2003, str. 141-144.

${ }^{6}$ Leon Stefanija, Topologija meril o slovenski glasbi po letu 1945: tradicionalno, moderno, postmoderno, Stoletja glasbe na Slovenskem, 20. slovenski glasbeni dnevi, ur. Primož Kuret, Ljubljana, Festival Ljubljana, 2006, str. 39.

7 I. Klemenčič, nav. delo, str. 324.

8 Nav. delo, str. 325.

9 Nav. delo. 
odvisni od aparatčikov ${ }^{10} \mathrm{v}$ institucionalni hierarhiji, ki so bili zadolženi za deljenje pogače. Čeprav odzivanje slovenskih skladateljev na represijo ni bilo enoznačno, so njihova prizadevanja $\mathrm{v}$ drugi polovici petdesetih let 20. stoletja postopoma izražala potrebo po svobodi ustvarjanja. Predvsem vokalna ustvarjalnost pa je bila podvržena nenehnim pritiskom po poljudnem in enostavnem. Oblast ni preprečevala stikov slovenskih s tujimi skladatelji, vendar je bilo v praksi slovenskim skladateljem izredno težavno sistematično vzpostaviti osebne kontakte z zahodom, ${ }^{11}$ kajti finančna pomoč za potovanja v tujino je bila zelo omejena in skrbno dodeljena. ${ }^{12}$ Slovensko glasbeno zgodovinopisje se je v spremenjenih razmerah moralo umakniti iz žive stvarnosti, oblast pa je iz preteklosti izbirala le sebi primerno. ${ }^{13}$ Zamolčano je v slovenski glasbeni zavesti zapustilo nenadomestljive in skorajda usodne posledice. Z izgubo zgodovinskega spomina je bil tako prihajajočim rodovom odvzet potreben kritični medij in onemogočen dialog s preteklostjo. ${ }^{14}$ Podobno tudi slovenska glasbena revialistika $v$ težavnih razmerah po vojni ni dosegla ravni iz začetka stoletja. ${ }^{15}$ Cerkvena glasba - deloma v povezavi z zatonom zahodnoevropske "meščanske« kulture - je bila na Slovenskem marginalizirana že z razpustitvijo osrednje slovenske meščanske glasbene združbe Glasbene matice po drugi svetovni vojni. Orglarska šola in revija Cerkveni glasbenik pa sta bili podobno kot Glasbena matica podvrženi načrtni ukinitvi. ${ }^{16}$ Takrat eden vodilnih partijskih ideologov Boris Kidrič ja-

${ }^{10}$ Aparatčik je aktivist oziroma funkcionar partijskega aparata, ki nekritično, brez premisleka izpolnjuje navodila nadrejenih. Gl. Slovar slovenskega knjižnega jezika, ur. Anton Bajec [...], Ljubljana, Državna založba Slovenije, 1994, str. 18.

${ }^{11}$ Tako je bilo prvo desetletje po vojni praktično onemogočeno sodelovanje z nekaterimi zahodnoevropskimi glasbenimi kulturami. Na festivale sodobne glasbe so namreč pošiljali bolj ali manj previdno izbrane člane v obliki delegacij jugoslovanskih skladateljev. Leon Stefanija, Totalitarnost režima in glasba, Muzikološke razprave. In memoriam Danilo Pokorn, ur. Nataša Cigoj Krstulović [...], Ljubljana, Založba ZRC, ZRC SAZU, 2004, str. 139.

${ }^{12}$ Kljub močnim ustvarjalnim osebnostim iz Osterčevega kroga med slovenskimi skladatelji ni prevladala nobena od takrat v svetu uveljavljenih kompozicijskih tehnik in estetik. Najpomembnejša dela gre še vedno pripisati skladateljem, ki so svojo pot našli že pred vojno. Nobena od skladateljskih generacij - tudi Pro musica viva v šestdesetih letih - tega mišljenjskega primanjkljaja ni več nadoknadila. Lojze Lebič, Glasovi časov (II), O slovenski glasbeni ustvarjalnosti, Naši zbori 45 (1993), 5-6, str. 114. O slovenski glasbeni avantgardi po drugi svetovni vojni glej tudi: Matjaž Barbo, Pro musica viva, Prispevek k slovenski moderni po II. svetovni vojni, Ljubljana, Znanstveni inštitut Filozofske fakultete, 2001.

${ }^{13}$ L. Lebič, Glasovi časov (II), nav. delo, str. 112-113.

${ }^{14} \mathrm{Na}$ praznino, ki je nastala zaradi izgube zgodovinskega spomina, je aktivno odgovoril Pavel Šivic, ko je leta 1957 osnoval napredno poustvarjalno skupino Collegium Musicum. To glasbeno združenje, ki je bilo odsev Šivičevih mednarodnih izkušenj - predvsem festivala ISCM - International Society for Contemporary Music 1957 v Zürichu - je naslednjih pet let Slovence načrtno seznanjalo z doslej zamolčanimi in nezaželenimi stranmi glasbe 20. stoletja. Nav. delo, str. 117.

15 Tako je bilo uredništvo Naših zborov že hudo zaskrbljeno, saj naj produkcija in kakovost povojne zborovske ustvarjalnosti ne bi več dosegali predvojne ravni. Pahor in Ravnik sta sicer videla vzroke v pomanjkljivem skladateljskem šolanju ter premiku proti instrumentalnosti. Vendar se zdi verjetno razloge iskati tudi v, zaradi besedila najbolj nedvoumni, ideološki izpostavljenosti omenjene zvrsti. Karol Pahor, Kriza v naši zborovski glasbi, Naši zbori 7 (1952), 3, str. 6-8. Glej tudi: Janko Ravnik, Še nekaj besed o krizi v zborovski glasbi, Naši zbori 8 (1953), 1-2, str. 2-3.

${ }^{16}$ Omenjena revija je ponovno začela izhajati šele leta 1976. 
nuarja 1951 na zasedanju politbiroja CK KPS govori o »ponovnih meščanskih silah iz klera«, ki naj bi bile eden izmed najmočnejših nasprotnikov socializma v Sloveniji. ${ }^{17}$ Vse v povezavi s cerkvijo se je tako znašlo v posebej nezavidljivih okoliščinah. ${ }^{18}$ Da je morala biti navzočnost cerkvene glasbe v javnosti resnično nezaželena prikazuje »incident « z duhovnikom in enim izmed vodilnih slovenskih cerkvenih skladateljev v 20. stoletju Matijo Tomcem, ${ }^{19}$ ki je bil prav zavoljo svoje odkrite katoliške usmerjenosti odrinjen na obrobje osrednjega glasbenega dogajanja na Slovenskem.

Akademski pevski zbor Tone Tomšič je sklenil 10-letnico ${ }^{20}$ svojega delovanja leta 1956 obeležiti z jubilejnim koncertom, na katerem naj bi po možnosti izvedli katero izmed izvirnih slovenskih celovečernih skladb, namesto dolge vrste posameznih kompozicij, kot je bilo na podobnih koncertih v navadi. ${ }^{21}$ Že oktobra leta 1954, se je pri Tomcu s prošnjo za uglasbitev oglasil takratni zborovodja Radovan Gobec. ${ }^{22}$ Tomc je kljub nekaterim pomislekom kot častni član APZ do zbora čutil posebno naklonjenost in sprejel Gobčevo povabilo. Ob 100-letnici rojstva Antona Aškerca se je na Gobčevo priprošnjo skladatelj odločil za uglasbitev Aškerčeve pesnitve Stara pravda.

${ }^{17}$ Leon Stefanija, Elusive Contents: Two Notes on Socialist Realism and Slovenian Music, Socialist realism and music, ur. Mikuláš Bek [...], Brno, Koniasch Latin Press, 2004, str. 163. Kidrič je na omenjenem zasedanju kot glavni problem slovenskega kulturnega okolja, s katerim se je soočala tedanja komunistična oblast poudaril prav »malomeščansko stihijo«. Darinka Drnovšek, Zapisniki politbiroja CK ZPS/ZKS 1945-1954, Ljubljana, Arhivsko društvo Slovenije, 2000, str. 257.

${ }^{18}$ Tudi izvajalci so le izjemoma posegali po cerkvenih skladbah. Med njimi najdemo: koncert v korist Rdečega križa 4. 11. 1946, ko je violinist Zlatko Baloković kot dodatek zaigral Schubertovo Ave Mario; Odo za dan svete Cecilije H. Purcella, ki jo je Orkester Radia Ljubljana zaigral na koncertu 11. 2. 1947 pod vodstvom Alena Buscha v Unionski dvorani; J. S. Bachu posvečeno akademijo 30. 3. 1950, kjer je dirigent D. Švara z orkestrom Akademije za glasbo izvedel dve Bachovi ariji (eno iz Pasijona po Mateju); slavnostn koncert, posvečen Jacobusu Gallusu med 7. in 12. 11. 1950, na katerih so izvedli tudi skladateljeve motete. L. Stefanija, Totalitarnost režima in glasba, nav. delo, str. 140 .

${ }^{19}$ Čeprav je bil tudi avtor vrste del za različne instrumentalne zasedbe, pa je bilo težišče njegovega ustvarjanja v vokalni ustvarjalnosti. Marijan Lipovšek v Slovenski glasbeni reviji leta 1957 zapiše: »Nedvomno je on za Adamičem naš prvi zborovski komponist.« Marijan Lipovšek, Koncertha sezona 1955/56, Slovenska glasbena revija 4 (1957), 1, str. 15.

${ }^{20}$ Akademski pevski zbor (APZ) je v omenjenem obdobju vodil Radovan Gobec. Zdi se, da so v slovenskem dnevnem časopisju kot začetek delovanja APZ razumevali povojno formacijo zbora, saj ne omenjajo 30-letnice od začetka delovanja moškega sestava APZ, ki ga je med letoma 1926 in 1941 vodil France Marolt. Kmalu po drugi svetovni vojni je namreč Gobec nadaljeval s tradicijo Maroltovega APZ, vendar je v zborovski sestav večinoma vključil nove pevce in zbor tudi prekvalificiral v mešanega. Jeseni 1953 je bilo tako na občnem zboru sklenjeno, da Gobčev APZ prevzame ime Maroltovega zbora in ga modificira v Akademski pevski zbor »Tone Tomšič«. Simona Moličnik Šivic, Mladi že 80 let: Akademski pevski zbor »Tone Tomšič«, Ljubljana, Narodna in univerzitetna knjižnica, 2006, str. 28.

${ }^{21}$ Edo Škulj, Tomčeve kantate, Tomčev zbornik, ur. Edo Škulj, Ljubljana, Družina, 1997, str. 19.

${ }^{22}$ Gobec naj bi prošnjo za uglasbitev naslovil na »starega prijatelja APZ in Maroltovega sodelavca ter njihovega častnega člana, skladatelja Matijo Tomca.« Slovenski poročevalec 16 (1955), 226, str. 4 (brez podpisa). Poizkusil naj bi tudi pri drugih skladateljih, vendar mu jih - z izjemo Tomca - za njegovo zamisel ni uspelo navdušit Škulj, Tomčeve kantate, nav. delo, str. 19. 
Pred uglasbitvijo je Tomc videl nekaj težko rešljivih problemov v zvezi z enormno dolžino pesnitve, ${ }^{23}$ izvajalskim aparatom ${ }^{24}$ in posebej pogostimi metričnimi spremembami Aškerčevega besedila, ${ }^{25}$ ki so skoraj 70 let od nastanka pesnitve odvračali skladatelje od uglasbitve tega monumentalnega Aškerčevega dela. Slednje v desetih delih simbolizira junaško epopejo slovensko-hrvaških kmečkih uporov, katerih žalostni višek je predstavljalo »kronanje« Matije Gubca v Zagrebu. ${ }^{26}$ Glede glasbenega izraza je skladatelj zapisal, da je hotel »združiti zdrav Aškerčev realizem s sodobnim, ne pretiranim glasbenim izrazom.«Že pred tem zapiše: »Gotovo ne bi kazalo iti po 70 letih nazaj v čas, ko je nastajala pesnitev Stara pravda, se pravi v čitalniško dobo. Vendar pa zopet ni kazalo postaviti skladbe, ki naj bi bila namenjena čim širšemu občinstvu, v okvire sodobne skrajnosti, recimo kar v atonalitetnost. Združiti zdrav Aškerčev realizem s sodobnim, ne pretiranim glasbenim izrazom: ta smoter sem imel pred očmi. $«{ }^{27}$ Vendar delo v ničemer ne izkazuje sodobnejših kompozicijsko-tehničnih prijemov, ki bi kakorkoli izstopali iz v tradicionalnejšo estetiko glasbe 19. stoletja naravnane miselnosti ter tako lahko bili sporni za nekatere najortodoksnejše zagovornike poljudnega in enostavnega v glasbi. ${ }^{28}$

${ }^{23}$ Leta 1980 je v koncertnem listu ob drugi izvedbi Stare pravde na koncertu društva Consortium musicum dne 16. maja 1980 zapisal: »Najprej dolžina pesnitve same. Sicer nima umetnost z računico nič opraviti, v tem slučaju pa prav pride. Stara pravda obsega 835 verzov. Prešernov Sonetni venec, ki ga je uglasbil Lucijan Marija Škerjanec pa denimo samo 210 verzov, se pravi 4 krat manj kot Stara pravda. V primeri s Sonetnim vencem bi tako Stara pravda uglasbena na podoben način, lahko obsegala 4 celovečerne koncerte. Zaželjen pa je bil seveda eden.« Matija Tomc, Uglasbitev Stare pravde. Koncert ob osemdesetletnici skladatelja Matije Tomca, Ljubljana, 16. maj 1980 [koncertni list društva Consortium musicum]. Da bi bilo možno uporabiti celoten tekst pesnitve, je Tomc k vokalnim odsekom dodal še recitatorja, saj je lahko le tako v dokaj kratkem času podal celotno besedilo pesnitve. Ker je v pesnitvi več mest, ki zahtevajo tudi soliste, je uporabil dva solista, v oporo pa jima dodal, kjer je bilo to potrebno tudi klavir. Slednje je bila premišljena poteza, kar dokazuje poročilo o koncertu iz Slovenskega poročevalca v letu 1956 (podpisan je bp) ki govori, da dramatizirani recitativ učinkuje odlično in v ničemer ne ruši njene glasbene harmonije. BP, »Pojó, pojó, da še nikdar tako...«, Slovenski poročevalec 17 (1956), 62, str. 5.

${ }^{24}$ Drugi problem s katerim je bil Tomc soočen je bil ali naj bo skladba zgolj vokalna ali vokalnoinstrumentalna, kot je običajno za kantate. Tome je dal prednost izključno vokalni skladbi saj je tudi APZ »Tone Tomšič« le vokalni ansambel. Načrtovana gostovanja v Zagrebu, Celju, Trbovljah, Mariboru in Beogradu so skladatelja dokončno odvrnila od instrumentacije omenjenega dela, saj naj bi »noben zbor, tudi če bi bil finančno še tako dobro situiran, ne bi mogel s seboj jemati orkestra na gostovanja po drugih mestih, najmanj pa seveda študentski zbor.« M. Tomc, nav. delo.

${ }^{25}$ Aškerc naj bi v Stari pravdi pogosto nenadoma spremenil ritem kot da bi se nekaj prelomilo. Za skladatelja, ki je večkrat s težavo prilagodil ritem skladbe pesnitvi, je nastopila nova težava, saj traja ta sprememba v pesnitvi komaj en ali dva verza. Tako naj bi bil potreben precejšen napor, da je skladatelj prilagodil omenjene metrične spremembe $\mathrm{v}$ pesnitvi ritmičnemu poteku v skladbi. Nav. delo.

${ }^{26}$ J. P., Pred jubilejnim koncertom Akademskega pevskega zbora. Aškerčeva »Stara pravda « v novi luči, Tedenska tribuna 4 (1956), 10, str. 9.

${ }^{27} \mathrm{M}$. Tomc, nav. delo.

${ }^{28}$ Nevarnosti odklona od »partijske linije«, ki so jih predstavniki oblasti iskali v umetniških delih in osebah, ki so iz različnih razlogov odstopali od deklarirane politične usmeritve, je »največji 
Kritika $^{29}$ v slovenskem dnevnem časopisju je pred jubilejnim koncertom »ob desetletnici uspešnega dela Akademskega pevskega zbora « ${ }^{30}$ napovedovala $»$ mogočno kantato ${ }^{31}$ za zbor, soliste, recitatorja in klavir. Slednja naj bi pomenila »bogat prispevek k slovenski zborovski literaturi « ${ }^{32}$ in sodila med skladateljeve »najpomembnejše stvaritve «. ${ }^{33}$ Naloga, ki si jo je zbor zadal, pa je »nedvomno zahtevala višek zborovske interpretacijske zmogljivosti« ter »prikazala vse njegove odlike pa tudi vse morebitne pomanjkljivosti «. ${ }^{34}$ Razen slavospevu Aškerčevemu svobodomiselnemu mišljenju, saj naj bi se ta »pogumno odrekel svojemu poklicu - duhovništvu «, ${ }^{35} \mathrm{v}$ dnevni kritiki ni zaznati izrazitejše ideološke obarvanosti. Slednja je napovedovala kulturni dogodek, ki naj bi v marsičem presegel takratne okvire »poljudnega« in »enostavnega« v glasbi.

»Brezštevilnim vajam « ${ }^{36}$ je 12 . marca 1956 sledila praizvedba v veliki Unionski dvorani. Tako kot nekateri vodilni partijski ideologi ${ }^{37} \mathrm{~s}$ častnim pokroviteljem koncerta Borisom Zihrlom na čelu, je skladatelj Tomc na prvo izvedbo svoje kantate »prišel v civilu in se skril v tretjo vrsto ${ }^{38}$ Uspeh po koncertu je bil velikanski. Kljub nekaterim manjšim pomanjkljivostim v interpretaciji, so si bili kritiki edini, da je »zbor popolnoma dorasel zahtevam, ki jih zastavlja ansamblu Tomčeva obdelava.« ${ }^{39}$ Kritik v Slovenskem poročevalcu pa je spregovoril celo o »lepo zvenečih sakralnih glasbenih intermezzih. ${ }^{40}$ Tako je Zmaga Kumer optimistično zapisala, da prav skladateljska moč Tomčeve umetniške osebnosti, svojski glasbeni izraz in neutrudna delavnost, Tomca uvrščajo med

ortodoksnež Boris Ziherl [...] videl na vsakem koraku.« Aleš Gabrič, Zajčeva Požgana trava v očeh partijskih ideologov, Nova revija 13 (1994), 147-148, str. 168.

${ }^{29}$ Značilno je, da se avtorji posameznih kritik v omenjenem dnevnem časopisju venomer podpisujejo le z začetnicami. Tako njihova identiteta ostaja prikrita, posledično pa ostaja vprašljiva tudi njihova strokovna kvalificiranost na glasbenem področju.

${ }^{30}$ Pred jubilejnim koncertom ob desetletnici uspešnega dela Akademskega pevskega zbora, Ljubljanski dnevnik 6 (1956), 58, str. 4 (brez podpisa).

${ }^{31}$ J. P., Pred jubilejnim koncertom Akademskega pevskega zbora, nav. delo, str. 9.

${ }^{32}$ J. G., Jubilejni koncert ob desetletnici Akademskega pevskega zbora, Ljubljanski dnevnik 6 (1956), 67, str. 4.

${ }^{33}$ J. P., Pred jubilejnim koncertom Akademskega pevskega zbora, nav. delo, str. 9.

${ }^{34}$ Nav. delo.

${ }^{35}$ Zaradi sporov z lavantinskim škofom, ki naj bi Aškercu očital svojeglavo razlaganje cerkvenih reči, je Aškerc po sedemnajstih letih duhovniške službe leta 1898 zaprosil za upokojitev. Aškerc, zavedni liberalec, naj bi ob tem doživel silovite napade klerikalnega tabora. Razloge za odločitev nekaterih intelektualcev za študij teologije pa dnevno časopisje vidi predvsem v gmotnih razmerah, ki naj bi »mladim sposobnim slovenskim inteligentom uničile življenske cilje in jih privedle v semenišče«. Nav. delo.

${ }^{36}$ Matjaž Kmecl, In memoriam Radovan Gobec (1. 6. 1909-14. 4. 1995), Naši zbori 47 (1995), $1-3$, str. 1 .

${ }^{37} \mathrm{Na}$ praizvedbi Tomčeve kantate so bili od vidnejših predstavnikov družbenega življenja prisotni še: podpredsednik Ljudske skupščine LRS dr. Ferdo Kozak, podpredsednik Izvršnega sveta LRS dr. Marijan Brecelj, član izvršnega sveta Boris Kocjančič in rektor ljubljanske univerze dr. ing. Anton Kuhelj. Jubilejni koncert APZ, Slovenski poročevalec 17 (1956), 61, str. 8 (brez podpisa).

${ }^{38}$ Matjaž Kmecl, Vrtičkarjevi zimski dnevi. Dr. Matjaž Kmecl: Dnevnik (1), Sobotna priloga, Delo 42 (2000), 12, str. 38.

${ }^{39}$ J. G., Jubilejni koncert ob desetletnici Akademskega pevskega zbora, nav. delo, str. 4.

${ }^{40} \mathrm{BP}, »$ Pojó, pojó, da še nikdar tako...«, nav. delo, str. 5. 
najvidnejše slovenske skladatelje ter obetajo, da bomo njegovo ime še in še srečevali na koncertnih sporedih. ${ }^{41}$ Žal je »incident v Unionski dvorani $\ll^{42}$ tovrstna pričakovanja obrnil na glavo.

Neljubi dogodek je namreč naletel na ostre odzive ortodoksnih partijskih ideologov, ki so zboru zamerili predvsem, da je po koncertu počastil skladateljski prispevek katoliškega intelektualca Matije Tomca. Vodstvo zbora naj bi namreč pred koncertom dobilo izrecno navodilo, da mora kulturni dogodek miniti brez osebne počastitve skladatelja. Kljub temu sta na Gobčev namig takratni predsednik in pevka APZ skladatelju v zahvalo izročila zlati lovorjev venec, Tomc pa se je skandirajočemu občinstvu dvakrat kar se da neopazno priklonil. Gobec je moral kot član partije že naslednji dan vrniti partijsko izkaznico, ${ }^{43}$ kasneje pa so ga zaradi Tomčevega duhovništva poklicali še na »pranje glave «. ${ }^{44}$ Pritisnili so na zbor tako močno, da je le ta izgubil dirigenta in tako skorajda razpadel v začetni, desetletje trajajoči povojni formaciji. ${ }^{45}$

Oznake so se iz političnega besednjaka kaj kmalu preselile v estetskega. ${ }^{46}$ Takratni

${ }^{41}$ Zmaga Kumer, Matija Tomc. Koncert ob desetletnici zbora in v počastitev stoletnice rojstva Antona Aškerca, Ljubljana, 12. marec 1956 [koncertni list APZ Tone Tomšič].

${ }^{42}$ S. B., Ven iz teme, Ob XII. občnem zboru Akademskega pevskega zbora »Tone Tomšič«, Tribuna 5 (1957), 16-17, str. 4.

${ }^{43}$ Po pripovedi gospoda Mitje Gobca, ki mu jo je kasneje zaupal njegov oče Radovan Gobec, se je moral slednji zaradi omenjenega »incidenta« že dan po praizvedbi kantate Stara pravda (13. marca 1956) zglasiti pri takratnem sekretarju OK ZKS Ljubljana Janezu Vipotniku. Vipotnik in Gobec naj bi se med seboj poznala in celo tikala. Tako naj bi po pripovedi gospoda Mitje Gobca na omenjenem sestanku Janez Vipotnik Gobca vprašal: »Radovan ali imaš s seboj partijsko knjižico [ter] ali mi jo pokažeš?« Gobec naj bi mu pokazal knjižico, Vipotnik pa naj bi jo nato »deponiral« v predal pisalne mize ter Gobca na tak način izključil iz partije. Mitja Gobec, elektronsko sporočilo poslano na elektronski naslov Jernej.Weiss@ff.uni-lj.si, 13. aprila 2007 ob 14.05.

$44 \gg$ Tomc je bil duhovnik in to je v tistem času napovedovalo zaplete, čeprav naj bil že pred vojno zaradi sodelovanja s Francetom Maroltom in Glasbeno matico tudi pri ,svojih' na ,slabem glasu'.« M. Kmecl, Vrtičkarjevi zimski dnevi. Dr. Matjaž Kmecl: Dnevnik (1), nav. delo, str. 38. Glej tudi: Aleš Gabrič, Izključitev Teološke fakultete iz Ljubljane, Slovenska kronika XX. stoletja: 1941-1995, ur. Marjan Drnovšek in Drago Bajt, Ljubljana, Nova revija, 1995, str. 189.

${ }^{45}$ Po gostovnaju v Zagrebu je pod pritiski Gobec podal odstop z mesta dirigenta APZ. Kritika pa je dogodek »razumela« nekoliko drugače, saj so njegov odstop povezovali s sprejetjem mesta direktorja Ljubljanskega festivala. Tako naj poslej Gobec za vodenje APZ ne bi imel več zadosti časa. S. B., Pro et contra, Peti in peti, Tribuna 5 (1957), 14, str. 4. Kljub temu se po pripovedi njegove soproge gospe Jožice Gobec zdi, da je Gobec odstopil predvsem zaradi nestrinjanja z represivnimi prijemi tedanje oblasti.

46 Tako je na primer v kritiki iz dnevnega časopisja mogoče zaslediti naslednja poročila: »Lani novembra je zbor štel štiriindevetdeset članov, danes pa je njegovo število upadlo pod sedemdeset.« S. B., Ven iz teme, Ob XII. občnem zboru Akademskega pevskega zbora »Tone Tomšič«, Tribuna 5 (1957) 16-17, str. 4. »Po tej večmesečni krizi naj bi se zbora vendarle usmilil dirigent Janez Bole.« S. B., Pro et contra, nav. delo, str. 4. Kritika je tako kmalu prikazala svoj drugi obraz, saj je bila poslej praizvedba Tomčeve kantate večinoma načrtno obarvana z barvo tretjerazrednosti. $\mathrm{V}$ dnevnem časopisju pa so se pojavili naslovi kot »Ven iz teme« idr. (S. B., Ven iz teme, nav. delo, str. 4), »saj naj bi kultura slovenskega zborovskega petja danes kljub mnogim finančnim podporam močno padla.« BP, »Pojó, pojó, da še nikdar tako...«, nav. delo, str. 5. 
odgovorni urednik Slovenskega poročevalca Sergej Vošnjak ${ }^{47}$ je farso izkoristil kot povod za napad na kritike, ki naj bi umetnost ocenjevali zgolj iz umetniških in brez upoštevanja političnih izhodišč. V daljšem članku z naslovom »Kritika kritike« manj kot mesec dni po incidentu 8. aprila 1956 v Slovenskem poročevalcu med drugim zapiše:

Mislim, da je osnovna slabost naše kulturne kritike v tem, da vsakega posameznega dela ne ocenjuje po njegovi celoti, po njegovi splošni družbeni vlogi, temveč skuša oddvojiti neki »estetski«, lahko bi celo rekli obrtniški del, kar naj bi bil predmet umetnostne kritike, od splošno družbenega pomena tega dela, s čimer naj se (po možnosti seveda čim manj!) ukvarjajo »politični« kritiki. [...] APZ »Tone Tomšič« je desetletnico svojega obstoja proslavil s korali. Človek je pričakoval, da bo zato osnovna misel kritike $\mathrm{v}$ tem, da bi tak zbor po svojem značaju in imenu moral $\mathrm{v}$ svoji pesmi povedati nekaj novega, naprednega. Kritika pa je govorila le o zvenu in ubranosti glasov... Govorila je tudi na splošno o problemu komponiranja posameznih ciklusov pesmi, izognila pa se je misli, da boj za staro pravdo ni bil sestavljen iz prošnje nebesom, ampak je bil trd in krut. Zato seveda takšna kritika APZ ne more prav nič koristiti, saj ne gre za to, da se dá neko formalno pohvalo, temveč za to, da mu ta kritika pomaga na boljšo pot, $\mathrm{k}$ boljšim uspehom, za katere ni najvažnejše, ali bo ta stavek zopet bolj ali manj fortissimo. ${ }^{48}$

Začetne, preveč naklonjene in premalo politične kritike so se torej morale umakniti »boljšim«, z očitki, da je tako revolucionaren ansambel ob svoji desetletnici prepeval »korale« in »prošnje nebesom « ${ }^{49}$ Tomc je hotel časopisno odgovoriti, da je »koralne«, natančneje glasbe z religiozno vsebino v dveurni celoti zgolj 18 taktov, pa še te bi za religiozne lahko označili le zaradi značaja Aškerčevega besedila (Primer 1).

V svojem odgovoru je Tomc nameraval zapisati, da je ob spornem odseku 18-ih taktov, ki naj bi bili manifestacija reakcionarnih protiljudskih tendenc, v partituri tudi oznaka »ironično« in »oponašajoče $«,{ }^{50}$ vendar si je kasneje premislil, saj bi s pismom, ki najverjetneje ne bi bilo objavljeno, stvar lahko še bolj zapletel. ${ }^{51}$ Da je šlo v omenjenem Vošnjakovem prispevku za obliko ždanovskega kulturnopolitičnega obračunavanja, je v svojem odgovoru v Slovenski glasbeni reviji jasno izpostavil Marijan Lipovšek, ki je edini javno obsodil zanj sporni način političnega obračunavanja $\mathrm{v}$ dnevnem časopisju: »Kritika tega dela [Stare pravde] ni pravilno vrednotila. Žal so se vmešali v oceno celo

\footnotetext{
${ }^{47}$ Vošnjak, Sergej (Ptuj, 6. 10. 1924 - Ljubljana, 13. 11. 2005), časnikar, kulturni delavec. Sodeloval je v NOB, bil je v uredništvu Mladine in kasneje Slovenskega pionirja. Po 2. svetovni vojni je bil med drugim urednik Mladine in Pionirja, od 1947 dopisnik Borbe iz Avstrije in urednik njene slovenske izdaje, nato direktor urada za informacije pri vladi Ljudske Republike Slovenije (1949-51), odgovorni urednik Slovenskega poročevalca (1951-59), glavni direktor časopisnozaložniškega podjetja Ljudska pravica (1961-67), urednik kulturne rubrike Dela (1967-73) in ravnatelj Mestnega gledališča ljubljanskega (1973-81). Pisal je članke, pesmi, skeče in črtice s partizansko in avtobiografsko motiviko. Lado Pohar, Vošnjak, Sergej, Enciklopedija Slovenije 14, ur. Dušan Voglar, Ljubljana, Mladinska knjiga, 2000, str. 362.

${ }^{48}$ Sergej Vošnjak, Kritika kritike, Slovenski poročevalec 17 (1956), 83, str. 6.

${ }^{49}$ Gre za odsek 18-ih taktov, ki se nahaja v 5. stavku z oznako Tlaka (odsek 4).

${ }^{50}$ Zbor (kmetje) namreč $\mathrm{v}$ zadnjih treh taktih omenjenega odseka recitativno oponaša graščaka.

${ }^{51}$ M. Kmecl, Vrtičkarjevi zimski dnevi. Dr. Matjaž Kmecl: Dnevnik (1), nav. delo, str. 38.
} 
Jernej Weiss: Vprašanje avtonomnosti glasbene kritike v slovenskem dnevnem časopisju ob praizvedbi ...

\section{Primer 1}
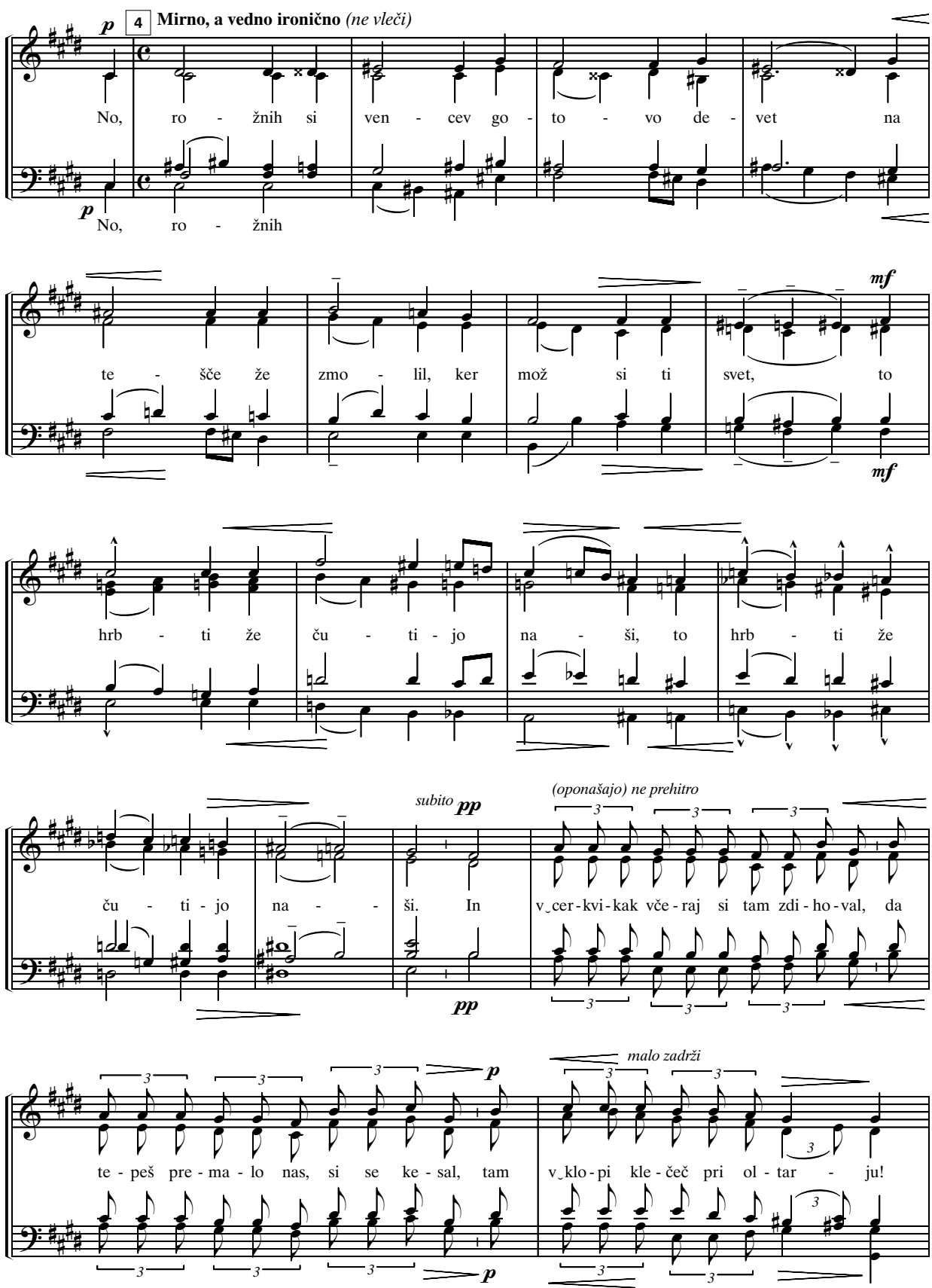

Matija Tomc: Stara pravda, 5. stavek (Tlaka), odsek 4. 
novinarji, ki so z diletantskimi opazkami skušali ne samo omalovaževati skladbo temveč so Tomcu podtikali neke 'pobožne' namene, ki jih on brez dvoma ni imel. Pri tem so klatili takšne neumnosti, da je bilo nam glasbenikom seveda jasno ko beli dan, kam pes taco moli. Široka publika pa, ki ima rešpekt pred glasbenimi problemi kompozicije, pa seveda tudi pred novinarjem, zlasti če je glavni in odgovorni urednik enega od dveh največjih časopisov, rada verjame, da je tako, kot je novinar napisal, zlasti ker je udobnejše in varnejše rep med noge stisniti. Tako pa je storila celo večina naše kritike. $\ll^{52} \mathrm{~V}$ prejšnji številki še zapiše: »Kolikor vem, nima Tomc svoji nadarjenosti, delavnosti in že storjenemu kompozitornemu delu ustrezajoče primerne zaposlitve. Odriniti takega skladatelja v Domžale na nižjo gimnazijo je slepota prve vrste. Tako se kultura ne podpira. ${ }^{53}$

Odprto polemiziranje pa ni ugajalo pravovernim partijskim ideologom, saj so menili, da boja za »umetnost nacionalnega v formi in socialističnega v vsebini ${ }^{54}$ ni primerno voditi na revijalnih straneh. Tako je tudi Lipovšek moral kmalu obmolkniti. Afero si je oblast kljub omiljenim stališčem do katoliške inteligence, ki so bila istega leta sprejeta na seji izvršnega komiteja Zveze komunistov Slovenije, ${ }^{55}$ zdi se razlagala kot poskus krepitve katoliškega idejnega vpliva. ${ }^{56}$

Kljub podobnemu sosledju dogodkov, pa bi glede na usodnost posledic omenjeni obračun le stežka primerjali denimo z uničujočim uvodnikom v uradnem partijskem glasilu Pravda (»Kaos namesto glasbe«) $)^{57}$ in posledično Šostakovičevi umetniški likvidaciji, ki je sprožila pravo gonjo proti tako imenovanim »formalističnim $\aleph^{58}$ skladateljem v Sovjetski zvezi. ${ }^{59}$

${ }^{52}$ Marijan Lipovšek, Koncertna sezona 1955/56, Slovenska glasbena revija 4 (1957) 1, str. 15.

${ }^{53}$ Marijan Lipovšek, Iz našega glasbenega življenja. Edicije DZS, Slovenska glasbena revija 3 (1955), 1-2, str. 41.

${ }^{54}$ Dmitri Schostakowitsch, Chaos statt Musik?. Briefe an einer Freund, ur. Isaak Dawydowitsch Glikman, Berlin, Argon, 1995, str. 30.

${ }^{55} \mathrm{Na}$ seji izvršnega odbora Centralnega komiteja Zveze komunistov Slovenije 29. oktobra 1956 je bil sprejet dogovor, da bi lahko pri nekaterih vprašanjih popustili in omilili stališča do verskega tiska, spomeniškega varstva, cerkvenih poslopij itd. Aleš Gabrič, Socialistična kulturna revolucija. Slovenska kulturna politika 1953-1962, Ljubljana, Cankarjeva založba, 1995, str. 185.

${ }^{56}$ Spreminjajoče se stališče takratnega slovenskega dnevnega časopisja se najbolj neposredno kaže v odnosu oblasti do Edvarda Kocbeka. Z načrtnim poizkusom medijskega discipliniranja katoliškega intelektualca Edvarda Kocbeka v prvih mesecih leta 1952, katerega posledica je bila njegova prisilna upokojitev, se je zdelo takratni oblasti nujno poslati jasen signal vsem drugim morebitnim prestopnikom. Aleš Gabrič, Intelektualci kot opozicija, Od programa Zedinjene Slovenije do mednarodnega priznanja Republike Slovenije 1848-1992, Slovenska novejša zgodovina 2, ur. Jasna Fischer [...], Mladinska knjiga, Ljubljana, 2005, str. 1025. Glej tudi: Aleš Gabrič, Kocbekov Strah in pogum, Slovenska kronika XX. stoletja: 1941-1995, ur. Marjan Drnovšek in Drago Bajt, Ljubljana, Nova revija, 1995, str. 185.

57 »Poslušalca od prvega trenutka te opere zbega nalašč nelepa, zmedena poplava zvokov. V ropotu, škripanju in cviljenju se utapljajo drobci melodije, zarodki glasbenih fraz, uidejo, pa se spet utopijo. Slediti tej ,glasbi‘ je težko, zapomniti si jo - nemogoče.« Salomon Volkov, Spomini Dmitrija Šostakoviča, kakor jih je slišal in uredil Solomon Volkov, Ljubljana, Nova revija, 2002, str. 23.

${ }^{58}$ Nicolas Slonimsky, Russian and Soviet Music and Composers, Writings on Music, ur. Electra Slonimsky Yourke, New York in London, Routledge, 2004, str. 215.

${ }^{59}$ Opera Lady Macbeth iz Mcenska, je bila premierno uprizorjena 22. januarja 1934 v Leningradu. 
10. februarja 1948 je tamkajšnji centralni komite zveze komunistov izdal resolucijo v kateri je obsodil neuspeh, da bi ustvarili glasbo sovjetskega realizma ter napadel skladatelje »formalističnih, protiljudskih tendenc $\ll .{ }^{60}$ Resolucija je med drugim pometla z najbolj nadarjenimi sovjetskimi skladatelji, med njimi s Šostakovičem in Prokofjevom ter obsodila skladatelje (Šebalina, Hačaturijana, Gavrila Popova in celo Mjaskovskega), ${ }^{61}$ »V delih katerih so formalistične sprevrženosti tuje sovjetskemu ljudstvu in njegovim umetniškim nagnenjem, še posebno kričeče «. ${ }^{62}$ Resolucija za razliko od dokaj ohlapnih političnih stališč, sprejetih na seji izvršnega komiteja Zveze komunistov Slovenije ${ }^{63}$ ne le konkretno daje prednost vokalnim kompozicijam pred instrumentalnimi, programski ${ }^{64}$ glasbi pred absolutno, ljudski pred elitistično, ${ }^{65}$ optimistični pred dekadentno, ${ }^{66}$ temveč postavlja tudi natančno določeno hierarhijo odgovornosti aparatčikov za učinkovito izvajanje enoglasno potrjenih sklepov. ${ }^{67}$ Kljub temu Šostakoviča zaradi njegove jurodivijske $^{68}$ vloge med protagonistom in žrtvijo sovjetskega režima ${ }^{69}$ za razliko od Tomca niso

28. januarja 1936 pa je v partijskem glasilu Pravda izšel uničujoč uvodnik, ki naj bi ga narekoval sam Stalin. Obsodbo omenjene opere gre razumeti predvsem kot opozorilo Šostakoviču in vsem ostalim »formalističnim《 skladateljem, da ne bi s svojimi »kaotičnimi« idejami še naprej ustvarjali nezdrave klime za ravoj sovjetske glasbe in kvarili mlajše generacije sovjetskih skladateljev. S. Volkov, nav. delo, str. 23.

${ }^{60}$ Nicolas Slonimsky, Music since 1900, 5. izdaja, New York, Schirmer, 1994, str. 1055-1057.

${ }^{61}$ Slednji je bil pred tem proglašen za enega najbolj reprezentativnih skladateljev sovjetskega realizma. Richard Taruskin, The Early Twentieth Century, The Oxford History of Western Music 4, Oxford, Oxford University Press, 2005, str. 777.

${ }^{62}$ N. Slonimsky, nav. delo, str. 1055-1057.

${ }^{63}$ A. Gabrič, Socialistična kulturna revolucija. Slovenska kulturna politika 1953-1962, nav. delo, str. 185.

${ }^{64}$ Predvsem glasbi s socialistično tematiko, ki naj bi slikala dosežke revolucije. N. Slonimsky, nav. delo, str. 1055-1057.

${ }^{65}$ Slednja naj bi bila nerazumljiva s svojo devijantnostjo in estetiko elitnega modernizma. Nav. delo.

${ }^{66}$ Nav. delo.

${ }^{67}$ Zdi se, da nikoli poprej tako eksplicitno - tudi ne v nacistični Nemčiji - niso bili skladatelji tako neposredno pozvani k epigonstvu predhodnjih skladateljskih generacij. Richard Taruskin, The Late Twentieth Century, The Oxford History of Western Music 5, Oxford, Oxford University Press, 2005, str. 11.

${ }^{68}$ Jurodivij ima dar, da vidi in sliši o čemer drugi nič ne vedo. Ampak v svojih videnjih pripoveduje svetu nalašč v paradoksih, v šifrah. Igra norca, medtem ko je v resnici vztrajen razkrinkovalec zla in nepravičnosti. Začetki jurodstva segajo v petnajsto stoletje in dlje nazaj. Kot opazen pojav je obstajalo še vse do osemnajstega stoletja. Ves čas so jurodiviji lahko obtoževali in ostajali razmeroma varni. Njihov vpliv je bil neznanski. Mnogi izobraženci so postali jurodiviji iz nekakšne intelektualne kritike, iz protesta. Šostakovič ni bil edini, ki je postal »nov jurodivij«. Ta vedenjski vzorec je postal v našem kulturnem okolju razmeroma priljubljen. Za moderne jurodivije je svet ležal v ruševinah, poizkus, da bi ustvarili novo družbo, pa se jim je - vsaj za tisti čas - zdel očitno obsojen na neuspeh. Zdelo se jim je, da je nove ideale mogoče potrjevati le »v nasprotju«. Sporočati jih je treba skozi zastor posmeha, sarkazma in prismojenosti. Ti umetniki so izbirali nepomembne, surove in namenoma okorne besede, da so izražali najglobje misli. Vendar te besede niso imele preprostega pomena. Vsebovale so dvojne ali trojne implikacije. S. Volkov, nav. delo, str. 20-21.

${ }^{69}$ Kakor je zapisal muzikolog Boris Asafjev je Šostakovič, »[...] pred nekakšnim notranjim konfliktom zbežal v območje napol pridigarstva napol jurodstva«. Nav. delo, str. 21. Čeprav je zavzel 
povsem izključili iz javnega življenja. Čeprav so njegova dela izginjala iz repertoarjev ter so se otroci v šolah na pamet učili besedil o »veliki škodi«, ki jo je Šostakovič naredil socialistični umetnosti, mu je bilo že naslednje leto po obračunu dodeljeno profesorsko mesto na leningrajskem konservatoriju.

V primerjavi z brutalnim medijskim terorjem takratnega sovjetskega dnevnega časopisja $^{70}$ in precej bolj neposrednim obračunavanjem v osrednjem nemškem glasbenem dnevniku Allgemeine Musik Zeitung po nacističnem prevzemu oblasti, ${ }^{71}$ se zdi glasbena kritika v drugi polovici petdesetih let na Slovenskem precej bolj rezervirana do odprtih ideoloških polemik ter konkretnih političnih obračunov. Čeprav se zdi, da ni šlo za »trdo« obračunavanje s »sovražnim elementom« ter da potemtakem slovenske različice totalitarnosti na glasbenem področju ne gre enačiti z okoliščinami in posledicami v politično primerljivih političnih ureditvah, ${ }^{72}$ je treba priznati, da bodo šele podrobnejše raziskave posameznih akterjev in institucij, ki jim raziskovalci do sedaj razen redkih izjem niso posvečali izdatnejše pozornosti, ${ }^{73}$ pripeljale do realnejše podobe povojnega slovenskega glasbenega dogajanja. Vsekakor v njem ni šlo zgolj »za splet okoliščin« temveč za načrtno preračunljivost visokih državnih organov, ki so brez odvečnega izpostavljanja, z namestitvijo v prvi vrsti politično lojalnih sodelavcev na uredniška in druga mesta, dosegli stopnjo represije povsem primerljivo z najbolj avtokratskimi sočasnimi političnimi režimi. Torej se zdi za skladatelje in glasbene poustvarjalce nevaren predvsem prefinjen način obračunavanja prek partijskih aparatčikov, ki je pripeljal do sila podobnih rezultatov kot neposredno zastrašujoče umetniške obsodbe: do samocenzure oziroma pisanja za predal. ${ }^{74}$

aktivno stališče nestrinjanja s političnim sistemom in to subtilno izrazil v glasbi, je v tujini še vedno veljal za enega vodilnih sovjetskih skladateljev. R. Taruskin, The Early Twentieth Century, nav. delo, str. 780-791.

${ }^{70} \mathrm{~V}$ slovenskem dnevnem časopisju skorajda ni mogoče naleteti na naslove kot so: »Dol z buržuazno estetiko in formalizmom «, »Dol z odvetniki kaosa v glasbi«, »Naj živi glasba za miljone« ipd.. N. Slonimsky, Russian and Soviet Music and Composers, Writings on Music, nav. delo, str. 90.

${ }^{71} »$ Arnold Schönberg in Franz Schrecker, profesorja mojstrske šole za kompozicijo na Glasbeni akademiji v Berlinu, sta suspendirana s strani Kulturnega ministrstva.« Personal-Nachrichten, Allgemeine Musik Zeitung, 60 (1933) 23, str. 316. Leta 1937 se je v nacistični Nemčiji uveljavilo označevanje izrojene glasbe s terminom »Entartete Musik« ter iz javnega življenja dokončno umaknjeni vsi glasbeniki židovskega rodu. R. Taruskin, The Early Twentieth Century, nav. delo, str. 754-756.

${ }^{72}$ L. Stefanija, Totalitarnost režima in glasba, nav. delo, str. 144.

${ }^{73}$ Med redke prispevke na glasbenem področju iz zadnjega obdobja, ki se dotikajo omenjene tematike bi lahko uvrstili: Ivan Klemenčič, Glasba in totalitarna država na Slovenskem, Temna stran meseca: kratka zgodovina totalitarizma v Sloveniji 1945-1990, ur. Drago Jančar, Ljubljana, Nova revija, 1998; Matjaž Barbo, Pro musica viva, Prispevek k slovenski moderni po II. svetovni vojni, Ljubljana, Znanstveni inštitut Filozofske fakultete, 2001; Leon Stefanija, Elusive Contents: Two Notes on Socialist Realism and Slovenian Music, Socialist realism and music, ur. Mikuláš Bek [...], Brno, Koniasch Latin Press, 2004 in Leon Stefanija, Totalitarnost režima in glasba, Muzikološke razprave. In memoriam Danilo Pokorn, ur. Nataša Cigoj Krstulović [...], Ljubljana, Založba ZRC, ZRC SAZU, 2004.

${ }^{74}$ D. Schostakowitsch, nav. delo, str. 31. Glej tudi: Borut Loparnik, Biti skladatelj. Pogovori s Primožem Ramovšem, Ljubljana, Slovenska matica, 1984, str. 90-92. 
Tako je Tomc v pismu Radovanu Gobcu iz leta 1973, ki ga je, zdi se, narekovala dolgoletna grenkoba, saj Stara pravda zaradi omenjenega dogodka nikoli poslej ni bila uvrščena na koncertni spored, ob proslavah večstoletnice kmečkih uporov na Slovenskem zapisal: »da s Staro pravdo oziroma njeno izvedbo tudi letos ne bo nič, sem bil takoj na jasnem, ko sem videl sestav odbora, ki je organiziral vse letošnje proslave. ${ }^{75}$ Takšnih in podobnih »političnih« odborov verjetno tudi v preteklosti ni manjkalo. Leta 1973 si je Tomc najbrže mislil, da je »kvalificirano javnost« tačas morebiti srečala pamet in da se bo v silnem navdušenju kmečko-puntnih proslav morda kdo le spomnil njegove glasbe. Vendar ni bilo tako. ${ }^{76}$

Če sta dva izmed najbolj brutalnih totalitarizmov v 20. stoletju v svojih najbolj surovih oblikah sovjetskega socrealizma in nemškega nacionalsocializma posebno pozornost namenjala umetnosti in posledično umetniško-politični kritiki, gre v primeru Tomčeve umetniške likvidacije za nekakšen poizkus prvenstveno političnega konstrukta. Njegov glavni namen se zdi obračun z duhovščino ${ }^{77}$ ter obenem discipliniranje kritike, s prikazom »pravilnih« smernic kritiškega pisanja. Le to naj ne bi bilo sposobno zadostnega uvida v družbeno nekoristnost zgolj »estetskega« pisanja in posledično nezmožno zadostne politične obsodbe »deviantnih« družbenih pojavov.

Zdi se, da sta Tome in Aškerc v strogo glasbenem oziroma literarnem oziru za takratno oblast precej manj sporna kot denimo Šostakovič in Leskov. ${ }^{78}$ Nova oblast je v drugi polovici petdesetih let 20. stoletja na Slovenskem navidez dajala občutek povsem avtonomnih odločitev glasbenih ustvarjalcev, vendar je preko različnih vzvodov dosledno pazila na zadostno stopnjo samocenzure. ${ }^{79}$ To je bila premišljena prilagodljivost, ki naj

${ }^{75}$ Pismo Matije Tomca Radovanu Gobcu (Domžale, 1973) hrani Gobčeva soproga gospa Jožica Gobec.

${ }^{76}$ Kantata je bila prvič ponovno izvedena šele 16. maja 1980 na koncertu društva Consortium musicum pod dirigentskim vodstvom dr. Mirka Cudermana (Koncert ob osemdesetletnici skladatelja Matije Tomca, Ljubljana, 16. maj 1980, Društvo Consortium musicum) ter nato 14. maja $2006 \mathrm{v}$ okviru Vokalnega abonmaja Slovenske filharmonije. Ponovno je pri izvedbi sodeloval zbor Consortium musicum, ki je kantato izvedel skupaj s Slovenskim komornim zborom pod dirigentskim vodstvom dr. Mirka Cudermana (8. koncert Vokalnega abonmaja Slovenskega komornega zbora, Ljubljana, 14. maj 2006, Slovenska filharmonija).

${ }^{77} \mathrm{~V}$ podobno nezavidljivi situaciji kot Tome sta se kmalu po koncu druge svetovne vojne znašla vsaj še dva izmed njegovih stanovskih kolegov: Stanko Premrl in Alojzij Mav. L. Stefanija, Totalitarnost režima in glasba, nav. delo, str. 141-142.

${ }^{78}$ Leskov, Nikolaj Semjonovič (Gorohovo, 16. 2. 1831 - Peterburg, 5. 3. 1895), ruski pisatelj. Izšel je iz uradniške družine, kasneje se je šolal v Orlu. Nato je opravljal službo uradnika v Kijevu in predstavnika angleškega trgovskega podjetja. Od 1860 je bil poklicni časnikar in nato državni uradnik, ki je živel večinoma v Peterburgu. Pisal je romane in predvsem povesti iz življenja ruskega ljudstva, posestnikov, kmetov, obrtnikov, uradnikov in podeželskih duhovnikov. $\mathrm{Z}$ omenjenimi deli, $v$ katerih prevladuje poudarjena satirična tendenca, je preoblikoval načela ruskega realističnega pripovedništva. Leta 1865 je napisal povest Lady Macbeth iz Mcenska. Vsevolod Setschkareff, N. S. Leskov: Sein Leben und sein Werk, Wiesbaden, Otto Harrassowitz, 1959, str. $3-38$.

${ }^{79}$ Predvsem preko nenapisanih pravil, posredno pa z dodeljevanjem denarnih sredstev in različnih bolj ali manj odločnih opozoril. A. Gabrič, Socialistična kulturna revolucija. Slovenska kulturna politika 1953-1962, nav. delo, str. 54-57. 
tudi za ceno ideološke doslednosti ohrani oblast in si na krilih samoupravljanja zagotovi močnejšo podporo v svetu. Navzven si je torej oblast predvsem skušala utrditi svojo brezmadežno samopodobo. Obseg ideološkega nadzora nad družbo se je tako z neposredno ustvarjalnega področja navidez skrčil, ${ }^{80}$ povsod drugje pa je ostal, tako na institucionalni ravni v kulturi in šolstvu ter seveda $\mathrm{v}$ kadrovski politiki.

Pregled kritike, obravnavane v pričujočem prispevku, še zdaleč ne zadostuje za postavitev okvira, ki bi začrtal ločnico med umetniškim in političnim v tedanji glasbeni kritiki na Slovenskem. Zdi se, da bi bil s kritičnim pretresom virov napravljen zgolj prvi korak v nizu temeljnih glasbeno-zgodovinopisnih nalog za določitev realnejše podobe nekaterih, danes že precej oddaljenih poglavij iz polpretekle slovenske glasbene zgodovine. Verjetno pa bi se lahko zgolj z upoštevanjem tovrstnih raziskav, dokončno obvarovali brezfaktičnih ideoloških polemiziranj, ki so skozi glasbeno zgodovino žal vse prevečkrat zaznamovale umetniške usode posameznikov.

THE QUESTION OF AUTONOMY OF MUSICAL REVIEW IN SLOVENE DAILY NEWSPAPERS ON THE FIRST PERFORMANCE OF THE CANTATA STARA PRAVDA (OLD JUSTICE) BY MATIJA TOMC: BETWEEN AN AESTHETIC JUDGEMENT AND A POLITICAL CONSTRUCT

\section{Summary}

One of the best Slovenian choirs, the Tone Tomšič Academic Choir, decided to celebrate its tenth anniversary with a jubilee concert. It was back in October 1954 that the then choirmaster, Radovan Gobec (1909-1995), visited the Slovenian composer Matija Tomc (1899-1986), asking him to set a poem to music. The latter felt special affection for the choir, and although feeling somewhat hesitant as a honorary member of the academic choir, he accepted Gobec's invitation. To mark the 100th anniversary of the birth of the Slovenian poet Anton Aškerc (1856-1912), the composer decided, at Gobec's request, to set to music the poem Stara pravda (Old Justice) by Aškerc.

The reviews in Slovenian daily newspapers announced a cultural event that would in many ways go beyond the framework of what was "popular" and "simple" in the music of that time. The concert was a huge success. Despite several minor shortcomings in the interpretation, the critics were unanimous that the choir completely satisfied the requirements appropriate to the ensemble in its performance of Tomc's setting. However, despite positive reviews, this cultural event caused sharp reactions among orthodox Marxist ideologists, who resented the fact that the choir's leaders rendered public homage to the contribution of the Catholic intellectual Matija Tomc as a composer. They put pressure on

${ }^{80} \mathrm{~Pa}$ še tu ga je bilo mogoče nadzirati, denimo z državnimi nagradami. I. Klemenčič, Glasba in totalitarna država na Slovenskem, nav. delo, str. 330. 
the choir so strongly that the latter lost its conductor, nearly disintegrating in its formative, decade-long post-war phase.

The terms of debate soon changed from a political vocabulary to an aesthetic one. The responsible editor of the newspaper of that time Slovenski poročevalec (Slovenian reporter), Sergej Vošnjak (1924-2005), used the farce as an occasion to attack the reviewers, who were taxed with merely assessing art from an artistic standpoint, without taking into account political criteria. The initial over-favourable and insufficiently numerous political reviews thus soon had to give way to "better ones" deploring that such a revolutionary ensemble should have sung "chants" and "pleas to Heavens" at its tenth anniversary. In a rejoinder in Slovenska glasbena revija (Slovenian Musical Review), the Slovenian pianist and composer Marijan Lipovšek (1910-1995), who was the only person publicly to condemn this manner of political reckoning in daily newspapers that he found questionable, pointed out clearly that Vošnjak's article revealed a cultural and political attitude worthy of Zhdanov.

Orthodox party ideologists, however, did not like open polemics, since, in their opinion, it was not appropriate that a socialist society should have to fight for socialist realism in art on magazine pages. Thus Lipovšek, too, was soon compelled to be silent. It seems that the authorities interpreted the affair as an attempt to strengthen the influence of Catholic ideas, despite the adoption of a more moderate attitude towards the Catholic intelligentsia in the same year at the session of the League of Communists of Slovenia's Executive Committee.

In comparison to the brutal media terror of Soviet daily newspapers and the considerably greater direct exercise of influence in German newspapers after the Nazi takeover of power, the world of music reviews in Slovenia in the second half of the Fifties seems only fairly mildly affected by concrete aesthetic or political directives. However, for composers and even more for performing artists, the subtle form of pressure exerted by party "apparatchiks" was equally dangerous. Through censorship, the latter achieved results very similar to those arising from directly threatening artistic condemnation through the operation of self-censorship and composition for the artist's own "drawer".

If two of the most brutal totalitarisms of the 20th century paid especial attention to art and, consequently, to the politicizing of reviews in the grossest forms taken by Soviet social realism and German National Socialism, Tomc's artistic liquidation involved a kind of attempt to put in place a political construct. Its main purpose seems to have been to combat the clergy while, at the same time, disciplining critics by showing them the "correct" guidelines for critical writing. The latter group were, so it was alleged, incapable of sufficient insight into the social uselessness of merely "aesthetic" writing and consequently unable to deliver a strong enough political condemnation to any "deviant" social phenomena. 